\title{
Utilization of fermented sago pulp as a source of carbohydrate in feed for Nile tilapia Oreochromis niloticus
}

\section{Pemanfaatan ampas sagu fermentasi sebagai sumber karbohidrat pada pakan ikan nila Oreochromis niloticus}

\author{
I Kadek Sumiana, Julie Ekasari ${ }^{1 *}$, Dedi Jusadi ${ }^{1}$, Mia Setiawati ${ }^{1}$ \\ 'Department of Aquaculture, Faculty of Fisheries and Marine Science, Bogor Agricultural University \\ *Corresponding author: j_ekasari@ipb.ac.id
}

(Received April 8, 2019; Accepted October 23, 2019)

\begin{abstract}
This study aimed to evaluate sago pulp fermentation method and its effect on crude fiber content, digestibility, and utilization of sago pulp as a feed raw material for Nile tilapia. Fermentation was done using three different fermenters, i.e. yeast tapai and baker's yeast with five doses of $10 \mathrm{~g} / \mathrm{kg}, 20 \mathrm{~g} / \mathrm{kg}, 50 \mathrm{~g} / \mathrm{kg}, 70 \mathrm{~g} / \mathrm{kg}, 100 \mathrm{~g} / \mathrm{kg}$, respectively, and sheep rumen liquid with five doses of $100 \mathrm{~mL} / \mathrm{kg}, 200 \mathrm{~mL} / \mathrm{kg}, 300 \mathrm{~mL} / \mathrm{kg}, 500 \mathrm{~mL} / \mathrm{kg}$ and $1000 \mathrm{~mL} / \mathrm{kg}$. The incubation time was $0,24,72$, and 96 hours. In the digestibility test, tilapia $(25 \mathrm{~g})$ was stocked at a density of 7 fish/aquarium. Three different diets were applied in quadruplicate, i.e. reference diet (100\% reference diet), unfermented sago pulp (AS), and fermented sago pulp (ASF). Three different dietary treatments (in quadruplicate) containing different carbohydrate sources were tested, i.e. cassava flour as a comparion $(\mathrm{G})$, unfermented sago pulp (AS), and fermented sago pulp (ASF). Fermentation of sago pulp with tapai yeast at a dose of $50 \mathrm{~g} / \mathrm{kg}$ at 72 hours incubation time could reduce crude fiber by $35.76 \%$, neutral detergent fiber (NDF) by $32.68 \%$, and hemicellulose by $60.39 \%$. Fermentation with yeast tapai could significantly increase sago pulp dry matter digestibility by $34 \%$ and carbohydrate digestibility by $21 \%$, as well as increase glucose absorption. The growth experiment showed that the use of ASF diets resulted in higher specific growth rate $(3.31 \pm 0.12 \%$ / day), protein retention $(47.34 \pm 5.23 \%)$ and fat retention $(85.58 \pm 5.44 \%)$ than those of AS dietary. In conclusion, fermentation of sago pulp using yeast tapai at a dose of $50 \mathrm{~g} / \mathrm{kg}$ at 72 hours incubation could reduce crude fiber content and increase dry matter and carbohydrate digestibilities, so that it can be used as a source of carbohydrates in tilapia diet.
\end{abstract}

Keywords : carbohydrate, digestibility, fermentation, fiber, Nile tilapia, sago pulp

\begin{abstract}
ABSTRAK
Penelitian ini bertujuan mengevaluasi metode fermentasi ampas sagu dan pengaruhnya terhadap kandungan serat kasar, kecernaan, dan pemanfaatan ampas sagu sebagai bahan baku pakan ikan nila. Fermentasi dilakukan dengan penambahan tiga perlakuan bahan fermentor yaitu ragi tape dan ragi roti ditambahkan dengan dosis masing-masing sebanyak $10 \mathrm{~g} / \mathrm{kg}, 20 \mathrm{~g} / \mathrm{kg}, 50 \mathrm{~g} / \mathrm{kg}, 70 \mathrm{~g} / \mathrm{kg}, 100 \mathrm{~g} / \mathrm{kg}$, dan cairan rumen domba yang ditambahkan dengan dosis $100 \mathrm{~mL} / \mathrm{kg}, 200 \mathrm{~mL} / \mathrm{kg}, 300 \mathrm{~mL} / \mathrm{kg}, 500 \mathrm{~mL} / \mathrm{kg}$, dan $1000 \mathrm{~mL} / \mathrm{kg}$. Lama waktu inkubasi 0, 24, 72, dan $96 \mathrm{jam}$. Pada uji kecernaan digunakan ikan nila (25 g) yang dipelihara dengan kepadatan tujuh ekor per akuarium. Pada uji ini dilakukan tiga perlakuan pakan dengan empat ulangan, yaitu pakan acuan, ampas sagu tanpa fermentasi (AS), dan ampas sagu fermentasi (ASF). Percobaan dilakukan dengan tiga perlakuan pakan (4 ulangan) dengan tiga sumber karbohidrat yang berbeda yaitu gaplek (G) sebagai pembanding, ampas sagu (AS), dan ampas sagu fermentasi (ASF). Fermentasi ampas sagu dengan menggunakan ragi tape sebanyak $50 \mathrm{~g} / \mathrm{kg}$ dengan lama inkubasi 72 jam dapat menurunkan serat kasar tertinggi sebanyak 35.76\%, dan menurunkan fraksi serat neutral detergent fiber (NDF) dan hemisellulosa masing-masing sebanyak 32.68\% dan 60.39\%. Perlakuan fermentasi ampas sagu dapat meningkatkan nilai kecernaan bahan sebesar 34\%, kecernaan karbohidrat sebesar 21\%, serta penyerapan glukosa. Hasil uji pertumbuhan menunjukkan bahwa perlakuan ASF memberikan nilai laju pertumbuhan spesifik $(3.31 \pm 0.12 \% /$ hari $)$, retensi protein $(47.34 \pm 5.23 \%)$ dan retensi lemak $(85.58 \pm 5.44 \%)$ yang lebih tinggi dibandingkan perlakuan AS $(\mathrm{P}<0.05)$. Dapat disimpulkan bahwa fermentasi ampas sagu dengan menggunakan ragi tape pada dosis $50 \mathrm{~g} / \mathrm{kg}$ selama 72 jam dapat menurunkan kadar serat kasar dan meningkatkan kecernaan bahan dan karbohidrat sehingga dapat digunakan sebagai sumber karbohidrat pada pakan ikan nila.
\end{abstract}




\section{INTRODUCTION}

Carbohydrate, in addition to protein and fat, is one of the macronutrients required in feed. The main function of carbohydrate is as an energy source and it is important for the development of a balanced feed for aquatic animals (Kamalam et al., 2017). Carbohydrate is also a feed component which shares a fairly large portion, especially for herbivorous and omnivorous fish. For example, the carbohydrate content in feed for Nile tilapia, which is an omnivorous fish, could reach 30 $35 \%$ (Opiyo, 2014). The common source of carbohydrate used in aquaculture feed is plantbased materials such as wheat pollard, corn, rice, bran, wheat flour, tapioca, gaplek (dried cassava root), and sago. In order to fulfill the need for raw materials for feed without being dependent on imported raw materials, it is very important to search for other local raw materials which have the potential to be used as a source of carbohydrate in fish feed, are abundant, and are waste-based or a secondary product so that the price is affordable.

One of the local raw materials which have the potential to be developed as a carbohydrate source is sago pulp. Indonesia has a sago plantation area of approximately 1,128 million Ha or $51.3 \%$ of the 2,201 million Ha global sago area with a productivity potential of 30 tons $/ \mathrm{ha} /$ year which exceeds other food sources such as rice (10-16 tons/ha/year) and corn (8-10 tons/ ha/year) by far (Alfons \& Rivaie, 2011). In the process of producing sago flour which is the main use of sago palms, waste in the form of sago pulp is produced at a rate of $14 \mathrm{~kg}$ wet pulp per $\mathrm{kg}$ sago flour (Yusuf, 2018). The main component of sago pulp is starch which varies between 30 and $73 \%$ of the dry weight (Adeni, 2013; Lai et al., 2013; Muhsafaat 2015). This sago pulp waste is not yet well utilized and could cause environmental issues if it is simply discarded (Tiro et al., 2018; Rosli, 2018; Amos 2010). In addition to its abundance as a secondary product of the sago flour processing industry, sago pulp is also a natural organic material which contains a low ash content. Some efforts to utilize this waste product are for sugar fermentation, as an enzyme, as fertilizer for mushrooms, and livestock feed with the purpose to decrease the pollution caused by the sago industry and also provide an economic solution to the waste management system in sago processing plants (Adeni et al., 2010).

Utilization of sago pulp as a material for fish feed is hindered by its high fiber content which could reach $18 \%$ with 16 to $28 \%$ of this being lignin which is difficult for fish to digest (Muhsafaat, 2015). The high crude fiber content could affect both the digestibility and palatability of the feed. Therefore, the utilization of sago pulp as an ingredient for fish feed needs to be preceded by decreasing the crude fiber and increasing the nutritional value which could be done through, among others, fermentation technology. Fermentation is a metabolic process where enzymes from microorganisms conduct hydrolysis and other chemical reactions which lead to chemical changes to an organic substrate (Sadh et al., 2018). Fermentation to foodstuff results in a number of benefits such as an improved quality both from the nutritional aspect and from the digestibility aspect, and an increased shelf life (Sanlier et al., 2017). A number of previous studies showed that fermentation treatment on various plant-based raw feed materials could reduce the crude fiber content. Previous studies revealed that sago pulp mixed with the contents of the rumen (70:30) fermented with Bacillus amyloliquefaciens at a dose of $2 \%$ for nine days at $40{ }^{\circ} \mathrm{C}$ could decrease its crude fiber by $33 \%$, from $24.75 \%$ to $16.56 \%$. Based on this background, the present study aimed to evaluate the fermentation method on sago pulp and its effect on the crude fiber content, digestibility, and utilization of sago pulp as a raw material for Nile tilapia Oreochromis niloticus feed.

\section{MATERIALS AND METHOD}

\section{Fermentation of the sago pulp}

The sago pulp used in the present study was waste obtained from a sago flour processing plant in Bogor, West Java. Wet sago pulp was sun dried for three days until the moisture content decreased to approximately $18 \%$. The sago pulp was then ground into flour and sifted using a $75 \mu \mathrm{m}$ (200 mesh) sieve.

The fermentation of the sago pulp was conducted by first steaming the sago pulp for 30 minutes and then cooling and weighing. The next step was adding the three fermentor treatments: tapai yeast, Baker's yeast, and sheep rumen fluid at different doses. Tapai yeast and Baker's yeast were added at different doses: $10 \mathrm{~g} / \mathrm{kg}, 20 \mathrm{~g} / \mathrm{kg}$, $50 \mathrm{~g} / \mathrm{kg}, 70 \mathrm{~g} / \mathrm{kg}$, and $100 \mathrm{~g} / \mathrm{kg}$, whereas the sheep rumen fluid was added at doses of $100 \mathrm{~mL} / \mathrm{kg}, 200$ $\mathrm{mL} / \mathrm{kg}, 300 \mathrm{~mL} / \mathrm{kg}, 500 \mathrm{~mL} / \mathrm{kg}$ and $1000 \mathrm{~mL} / \mathrm{kg}$. The fermentors were then thoroughly mixed with the sago pulp flour and subsequently placed in 
black plastic bags, tighthened with rubber bands and placed in canisters for an incubation period of 96 hours. After that, samples from each treatment were collected every 24 hours for crude fiber testing. The fermented sago pulp was then heated in an oven for $1-2$ hours at $60^{\circ} \mathrm{C}$. The fermentor which could decrease the greatest amount of crude fiber, tapai yeast at a dose of $50 \mathrm{~g} / \mathrm{kg}$ incubated for 72 hours, was used as a reference for fermenting the sago pulp in the next stage (the digestibility test). Before and after the fermentation treatment, an analysis of the crude fiber and fiber fraction content were conducted on the sago pulp using the Van Soest method (1991).

\section{Digestibility test}

\section{Experimental diet formulation}

The second stage of the study was to evaluate the digestibility of the raw materials, i.e unfermented sago pulp flour and sago pulp flour fermented with tapai yeast at a dose of $50 \mathrm{~g} / \mathrm{kg}$ for 72 hours. The research design in the digestibility test was a complete randomized design with 3 dietary treatments with 4 replications, i.e. reference diet (RD), unfermented sago pulp feed (AS), and fermented sago pulp feed (ASF).

The digestibility test was conducted based on Watanabe (1988) with a composition of $70 \%$ reference diet and 30\% test material. The composition of the experimental diets used in the present study is presented in Table 1.

Fish maintenance and the collection of the digestibility test data

Seven Nile tilapia juveniles with an average weight of $25 \mathrm{~g}$ were kept in a $60 \times 40 \times 50 \mathrm{~cm}^{3}$ aerated aquarium. The tested fish were adapted to the experimental diet for a week with a feeding frequency of three times a day at 08:00 AM, 1:00 $\mathrm{PM}$, and 5:00 PM. After the adaptation period, the fish were fasted for 24 hours and then fed with the experimental diets and had their feces collected for 20 days from day three after the first day of experimental diet administration. The feed

Table 1. Composition and proximate composition of experimental diets in digestibility test

\begin{tabular}{|c|c|c|c|}
\hline \multirow{2}{*}{ Feed composition $(\%)$} & \multicolumn{3}{|c|}{ Treatment feed } \\
\hline & $\mathrm{RD}$ & AS & ASF \\
\hline Fish meal & 20 & 13.94 & 13.94 \\
\hline Soybean flour & 24 & 16.73 & 16.73 \\
\hline Wheat flour & 52 & 36.24 & 36.24 \\
\hline Palm oil & 2 & 1.39 & 1.39 \\
\hline Sago pulp & - & 30 & - \\
\hline Fermented sago pulp & - & - & 30 \\
\hline Premix vit $+\min ^{1}$ & 1 & 0.7 & 0.7 \\
\hline Binder & 0.4 & 0.4 & 0.4 \\
\hline $\mathrm{Cr}_{2} \mathrm{O}_{3}$ & 0.6 & 0.6 & 0.6 \\
\hline \multicolumn{4}{|l|}{ Feed proximate (\% dry weight) } \\
\hline Protein $(\%)$ & 33.40 & 26.39 & 27.26 \\
\hline Fat $(\%)$ & 6.41 & 4.14 & 4.65 \\
\hline Ash (\%) & 8.26 & 8.98 & 8.37 \\
\hline Crude fiber $(\%)$ & 3.68 & 9.22 & 6.93 \\
\hline $\operatorname{NFE}^{2}(\%)$ & 48.25 & 51.27 & 52.79 \\
\hline $\mathrm{GE}^{3}(\mathrm{kcal} / \mathrm{kg})$ & 4442 & 3817 & 4126 \\
\hline
\end{tabular}

${ }^{1}$ Each gram of premix contained 50 IU of vitamin A, 10 IU of vitamin D, 0.60 IU of vitamin E, 50 mcg of vitamin $\mathrm{K} 3,100 \mathrm{mcg}$ of vitamin B1, $200 \mathrm{mcg}$ of vitamin B2, $650 \mathrm{mcg}$ of vitamin B3, $300 \mathrm{mcg}$ of vitamin B5, $0.25 \mathrm{mcg}$ of vitamin B6, $5 \mathrm{mcg}$ of vitamin B7, $40 \mathrm{mcg}$ of vitamin B9, 0.250 of vitamin B12, $400 \mathrm{mcg}$ of vitamin C, 2000 mcg of stay-c, $3000 \mathrm{mcg}$ of $\alpha$-tocopherol acetate, $1000 \mathrm{mcg}$ of inositol, $3000 \mathrm{mcg}$ of choline chloride, $280 \mathrm{mcg}$ of phosphorus, $5600 \mathrm{mcg}$ of potassium, $5600 \mathrm{mcg}$ of calcium, $1820 \mathrm{mcg}$ of magnesium, $8400 \mathrm{mcg}$ of sodium, 196 mcg of iodine, $1.4 \mathrm{mcg}$ of copper, $332 \mathrm{mcg}$ of iron, $3.5 \mathrm{mcg}$ of manganese, $33.6 \mathrm{mcg}$ of zinc, $50 \mathrm{mcg}$ of cobalt, 10 mcg of selenium, $3000 \mathrm{mcg}$ of $\mathrm{CaHPO}_{4}, 1400 \mathrm{mcg}$ of $\mathrm{NaCl}$, and $500 \mathrm{mcg}$ of phytase.

${ }^{2} \mathrm{NFE}$ : Nitrogen-Free Extract.

${ }^{3} \mathrm{GE}$ : Gross Energy, $1 \mathrm{~g}$ protein $=5.6 \mathrm{kcal}, \quad 1 \mathrm{~g}$ fat $=9.4 \mathrm{kcal}, 1 \mathrm{~g}$ carbohydrate $/ \mathrm{NFE}=4.1 \mathrm{kcal}($ Watanabe,1998). 
was given to apparent satiation with a frequency of three times a day (Watanabe, 1988). The feces were collected using a siphoning hose 30 minutes after feeding after the leftover feed was removed from the water. The feces was then collected and stored at $-20^{\circ} \mathrm{C}$ until further analysis. The feces was then dried in an oven at $110^{\circ} \mathrm{C}$ for $4-6$ hours, prior to protein, carbohydrate, and energy content analyses. The measurement of $\mathrm{Cr}_{2} \mathrm{O}_{3}$ in the feces was conducted using a spectrophotometer with a $350 \mathrm{~nm}$ wavelength according to the procedure in Takeuchi (1988). The parameters observed in this digestibility test included:

$$
\operatorname{ADC}(\%)=\left[1-\left(\frac{\mathrm{NP}}{\mathrm{NF}} \times \frac{\mathrm{IP}}{\mathrm{IF}}\right)\right]
$$

\section{Notes:}

$\mathrm{ADC}=$ Feed digestibility coefficient

$\mathrm{NP} \quad=$ Nutrient in feed $(\%)$

$\mathrm{NF} \quad=$ Nutrient in feces $(\%)$

IF $\quad=\mathrm{Cr}_{2} \mathrm{O}_{3}$ in feces $(\%)$

IP $\quad=\mathrm{Cr}_{2} \mathrm{O}_{3}$ in feed $(\%)$
$\mathrm{DE}(\mathrm{kcal} / 100 \mathrm{~g})=\mathrm{Ep}-\left[\mathrm{Ef} \times\left(\frac{\mathrm{IP}}{\mathrm{IF}}\right)\right]$

Notes:

$\mathrm{DE}=$ Digested energy $(\mathrm{kcal} / 100 \mathrm{gr})$

Ep $\quad=$ Energy in feed material $(\mathrm{kcal} / 100 \mathrm{gr})$

Ef = Energy in feces (kcal/100gr)

IP $\quad=\mathrm{Cr}_{2} \mathrm{O}_{3}$ in feed $(\%)$

IF $\quad=\mathrm{Cr}_{2} \mathrm{O}_{3}$ in feces $(\%)$

$$
\operatorname{ADC}(\%)=\left[1-\left(\frac{\mathrm{NP}}{\mathrm{NF}} \times \frac{\mathrm{IP}}{\mathrm{IF}}\right)\right]
$$

Notes:

$\mathrm{ADC}=$ Feed carbohydrate/protein digestibility coefficient

$\mathrm{NP}=$ Feed carbohydrate/protein content $(\%)$

$\mathrm{NF}=$ Feces carbohydrate/protein content

$(\%)$

IF $\quad=\mathrm{Cr}_{2} \mathrm{O}_{3}$ in feces $(\%)$

IP $\quad=\mathrm{Cr}_{2} \mathrm{O}_{3}$ in feed $(\%)$

\begin{tabular}{|c|c|c|c|}
\hline \multirow[b]{2}{*}{ Feed composition $(\%)$} & \multicolumn{3}{|c|}{ Treatment feed } \\
\hline & G & AS & ASF \\
\hline Fish meal & 7 & 7 & 7 \\
\hline РBPM & 21 & 20 & 20 \\
\hline Soybean flour & 27 & 27 & 26 \\
\hline Bran & 9 & 12.5 & 11.2 \\
\hline Wheat flour & 10.5 & 8 & 10.3 \\
\hline Cassava flour & 18 & - & - \\
\hline Sago pulp & - & 18 & - \\
\hline Fermented sago pulp & - & - & 18 \\
\hline Coconut oil & 1.5 & 1.5 & 1.5 \\
\hline Corn oil & 2 & 2 & 2 \\
\hline Premix vit + minerals & 2 & 2 & 2 \\
\hline Binder & 2 & 2 & 2 \\
\hline \multicolumn{4}{|l|}{ Proximate feed ( $\%$ dry weight) } \\
\hline Protein $(\%)$ & 32.05 & 31.97 & 32.37 \\
\hline Fat $(\%)$ & 5.51 & 5.71 & 5.51 \\
\hline Ash (\%) & 8.52 & 8.25 & 8.43 \\
\hline Crude fiber $(\%)$ & 2.28 & 5.02 & 3.75 \\
\hline NFE $(\%)$ & 35.49 & 32.48 & 33.56 \\
\hline $\mathrm{GE}(\mathrm{kcal} / \mathrm{kg})$ & 4098 & 3989 & 4037 \\
\hline $\mathrm{C} / \mathrm{P}$ & 12 & 12 & 12 \\
\hline
\end{tabular}

Table 2. Composition and proximate composition of the experimental diets in growth test

Notes: $\mathrm{G}=18 \%$ gaple $;$; $\mathrm{AS}=18 \%$ sago pulp; $\mathrm{ASF}=18 \%$ fermented sago pulp; $\mathrm{NFE}=$ Nitrogen-Free Extract; $\mathrm{GE}=$ gross energy, $1 \mathrm{~g}$ protein $=5.6 \mathrm{kcal}, 1 \mathrm{~g}$ fat $=9.4 \mathrm{kcal}, 1 \mathrm{~g}$ carbohydrate $4.1 \mathrm{kcal}$ (Watanabe, 1988); PBPM= poultry by-product meal. 
The digestibility rate of each test material used could be calculated using an equation suggested by Watanabe (1988):

$$
\text { Material digestibility }=(\mathrm{ADT}-0.7 \mathrm{AD}) / 0.3
$$

Notes:

$\mathrm{ADT}=$ test feed digestibility rate

$\mathrm{AD} \quad=$ reference feed digestibility rate

\section{Measurement of blood glucose content}

The present study also conducted an observation of the blood glucose concentration before and after the administration of the tested diet. Before the blood collection, the fish were not fed for 24 hours. The blood was then collected at 0 hours (prior to feeding). The fish were then fed to satiation and blood was collected at 1, 2, 3, 4 and 5 hours post feeding. Blood samples were collected from the caudal vein using a $1.5 \mathrm{~mL}$ syringe that had been rinsed with $3.8 \%$ sodium citrate anticoagulant. One $\mathrm{mL}$ of the blood sample was placed in a $1.5 \mathrm{~mL}$ microtube and centrifuged at $3000 \mathrm{rpm}$ for 10 minutes (Wedemeyer \& Yasutake, 1977) for the measurement of blood plasma glucose and then analyzed using an ortho-toluidine reactant (Dubowski, 2008) and spectrophotometer at a wavelength of $530 \mathrm{~nm}$.

\section{Growth test}

\section{Experimental diets formulation}

The growth test compared three types of experimental diets, i.e. diet with $18 \%$ cassava flour as the source of carbohydrate $(\mathrm{G})$ as the comparative feed and feed with unfermented sago pulp flour (AS) and fermented sago pulp flour (ASF) as the source of carbohydrate, each $18 \%$ (Table 2). Cassava flour was used as the comparative material because this material is one of the carbohydrate sources commonly used in the production of fish feed in Indonesia (Henriksson et al., 2017).

\section{Fish maintenance during the growth test}

In the growth test, Nile tilapia juveniles with an average initial weight of $3.73 \pm 0.08 \mathrm{~g}$ were kept in twelve units of $60 \times 50 \times 40 \mathrm{~cm}^{3}$ aquariums with a water volume of $75 \mathrm{~L}$. The fish were stocked at a density of 15 individuals per aquarium and were kept for 60 days. The feed was given to apparent satiation with a feeding frequency of three times a day at 08:00, 12:00, and 16:00.

Throughout the maintenance period, the water quality was maintained at an optimum range for the growth and survival of Nile tilapia by daily siphoning to remove any leftover feed and feces, and by replacing $50 \%$ of the water every 4 days. Each aquarium was equipped with a thermostat to maintain a stable temperature, aeration to regulate dissolved oxygen, and a top filter to reduce turbidity and ammonia concentration. The water temperature was measured daily in the morning, whereas the measurements of $\mathrm{pH}$ and dissolved oxygen were taken at the beginning, in the middle, and at the end of the maintenance period. Weight sampling was conducted three times during the course of the maintenance period.

At the beginning of the maintenance period, the fish's initial weight was recorded and 25 fish were collected as samples for the initial proximate analysis. At the end of the maintenance period, all the fish in every aquarium were weighed and 5 fish were collected for blood sampling for the blood profile observation (erythrocytes, leukocytes, and phagocytic activity) and then dissected to collect the livers for measuring the hepatosomatic index (HSI) and liver glycogen content. In addition, some of the samples were also used for the final fish proximate analysis as a basis for calculating the protein and fat retention.

\section{Test parameters}

The test parameters observed in this stage included the fish growth performance, the liver glycogen content, HSI, and protein and fat retention. The fish growth performance parameters included fish survival, specific growth rate, total feed intake, and feed conversion ratio. The specific growth rate (SGR) and feed conversion ratio (FCR) were calculated based on the equation suggested by Huisman (1987). The total feed intake (TFI) was determined by weighing the feed given during the maintenance period. The survival was calculated based on the proportion of fish that were still alive at the end of the maintenance period.

Extraction and hydrolysis of the liver were conducted based on the method by Watanabe (1988), while the liver glycogen analysis was conducted based on Dubowski (2008). The HSI value was calculated based on the ratio between the liver weight and the fish's total body weight. Protein retention and fat retention were calculated using a proximate analysis of the test fish's initial and final body protein and the fish feed protein. The equation used to calculate protein retention or fat retention is as follows (Takeuchi, 1988):

$$
\mathrm{RP} / \mathrm{RL}=\frac{\mathrm{F}-\mathrm{I}}{\mathrm{P}} \times 100
$$


Notes:

$\mathrm{RP} / \mathrm{RL}=$ Protein or fat retention $(\%)$

$\mathrm{F} \quad=$ The amount of the fish's protein/fat at the end of the maintenance period

I = The amount of the fish's protein/fat at the beginning of the maintenance period

$\mathrm{P} \quad=$ The amount of protein/fat consumed

\section{Proximate analysis of the feed and the fish}

Proximate analyses were conducted on the feed raw material, experimental diets, and fish which consisted of the crude protein content which was conducted using the Kjeldahl method, the crude fat content which was conducted using the Soxhlet method, the fat content with the Folch method, the ash content by heating the samples in a furnace at $600^{\circ} \mathrm{C}$, the crude fiber by dissolving the samples using strong acids and bases and heating them, and the moisture content by heating the samples in an oven at $105-110^{\circ} \mathrm{C}$ (Takeuchi, 1988).

\section{Statistical analysis}

The measurement data were calculated using Microsoft Excel. The crude fiber content data were analyzed descriptively, while the fiber fraction, digestibility, and growth performance data were analyzed statistically using the SPSS version 16.0 statistical software. For the fiber fraction and digestibility test, the ratio between unfermented and fermented sago pulp flour was obtained using the T-test at a confidence interval of $95 \%$, whereas the growth performance data were analyzed using the ANOVA test at a confidence interval of $95 \%$. Before the ANOVA test, the homogeneity of variances and data normality were tested using the Kolmogorov Smirnov test. If the ANOVA test gave a significantly different result, the analysis of variance between treatments was continued with Duncan's test.

\section{RESULTS AND DISCUSSION}

\section{Results \\ The fermentation of sago pulp}

The results of the first stage of the study which was the fermentation of sago pulp are presented in Table 3. The greatest decrease in crude fiber was seen in the treatment with tapai yeast at a dose of $50 \mathrm{~g} / \mathrm{kg}$ and an incubation period of 72 hours, decreasing the crude fiber by $35.76 \%$. On the other hand, the sheep rumen treatment at various doses and incubation periods did not demonstrate any effect on the sago pulp crude fiber content.

Table 3. The crude fiber \% content of sago pulp flour fermented using three different fermentors with different doses and incubation periods

\begin{tabular}{ccccccc}
\hline \multirow{2}{*}{ Fermentor } & Dose & \multicolumn{5}{c}{ Incubation period (hours) } \\
\cline { 2 - 6 } & $0 \mathrm{~g} / \mathrm{kg}$ & 18.76 & 18.76 & 18.76 & 18.76 & 18.76 \\
\cline { 2 - 6 } Tapai yeast & $10 \mathrm{~g} / \mathrm{kg}$ & 18.56 & 18.45 & 17.80 & 16.00 & 15.00 \\
& $20 \mathrm{~g} / \mathrm{kg}$ & 19.11 & 18.45 & 16.20 & 14.40 & 13.23 \\
& $50 \mathrm{~g} / \mathrm{kg}$ & 18.76 & 18.45 & 15.38 & 12.05 & 13.12 \\
& $70 \mathrm{~g} / \mathrm{kg}$ & 19.00 & 18.88 & 16.10 & 12.23 & 13.09 \\
& $100 \mathrm{~g} / \mathrm{kg}$ & 19.22 & 18.20 & 16.55 & 13.42 & 13.18 \\
\hline \multirow{5}{*}{ Baker's yeast } & $0 \mathrm{~g} / \mathrm{kg}$ & 18.76 & 18.76 & 18.76 & 18.76 & 18.76 \\
& $10 \mathrm{~g} / \mathrm{kg}$ & 19.00 & 18.86 & 16.54 & 16.00 & 16.00 \\
& $20 \mathrm{~g} / \mathrm{kg}$ & 19.05 & 18.56 & 18.23 & 16.22 & 14.11 \\
& $50 \mathrm{~g} / \mathrm{kg}$ & 18.91 & 18.00 & 15.44 & 15.07 & 15.39 \\
& $70 \mathrm{~g} / \mathrm{kg}$ & 19.20 & 18.00 & 16.60 & 15.00 & 14.91 \\
& $100 \mathrm{~g} / \mathrm{kg}$ & 19.88 & 18.00 & 17.35 & 15.80 & 14.88 \\
\hline \multirow{3}{*}{ Sheep rumenyyyyy fluid } & $0 \mathrm{~mL} / \mathrm{kg}$ & 18.76 & 18.76 & 18.76 & 18.76 & 18.76 \\
& $100 \mathrm{~mL} / \mathrm{kg}$ & 19.20 & 19.00 & 18.76 & 19.40 & 19.89 \\
& $200 \mathrm{~mL} / \mathrm{kg}$ & 18.68 & 18.70 & 18.00 & 19.00 & 18.00 \\
& $300 \mathrm{~mL} / \mathrm{kg}$ & 19.00 & 19.30 & 19.07 & 19.00 & 19.00 \\
& $500 \mathrm{~mL} / \mathrm{kg}$ & 19.00 & 18.30 & 18.00 & 18.00 & 18.00 \\
& $1000 \mathrm{~mL} / \mathrm{kg}$ & 19.21 & 19.22 & 18.60 & 18.17 & 19.72 \\
\hline
\end{tabular}


Table 4. The proximate composition of unfermented sago pulp and after fermentation with tapai yeast at a

\begin{tabular}{cccc} 
dose of $50 \quad \mathrm{~g} / \mathrm{kg}$ & for & 72 & hours. \\
\hline Nutrient (\% dry weight) & AS & ASF \\
\hline Protein & 1.72 & 6.23 \\
Fat & 0.5 & 0.49 \\
Moisture content & 15 & 13.7 \\
Ash content & 6 & 7.31 \\
Crude fiber & 18.76 & 12.05 \\
NFE & 58.02 & 60.22 \\
\hline Notes: AS= Sago pulp; ASF= Fermented sago pulp;
\end{tabular} $\mathrm{NFE}=$ Nitrogen-free extract.

The effects of fermentation using $50 \mathrm{~g} / \mathrm{kg}$ tapai yeast at a 72 hour incubation period on changes in the sago pulp nutrients are presented in Table 4. The results of the protein content, fat content, ash content, crude fiber content, and nitrogenfree extract (NFE) analyses revealed that there was a $35.76 \%$ decrease in the sago pulp's crude fiber content from $18.76 \%$ to $12.05 \%$, and protein content increased 2.6 times from $1.72 \%$ to $6.23 \%$. On the other hand, the ash content, moisture content, fat content, and NFE demonstrated only little change.

Treatment by fermentation using $50 \mathrm{~g} / \mathrm{kg}$ tapai yeast for 72 hours could decrease the neutral detergent fiber (NDF) fraction by $32.68 \%$ and hemicellulose by $60.39 \%$, whereas the acid detergent fiber (ADF), cellulose, and lignin contents did not undergo any significant changes (Figure 1).

\section{Digestibility test}

The results of the digestibility test on sago pulp fermented with tapai yeast at a dose of 50 $\mathrm{mg} / \mathrm{kg}$ and incubation period of 72 hours revealed that the fermentation of the material had a significant effect on the dry material digestibility and carbohydrate digestibility but not on the protein digestibility or energy digestibility (Figure 2).

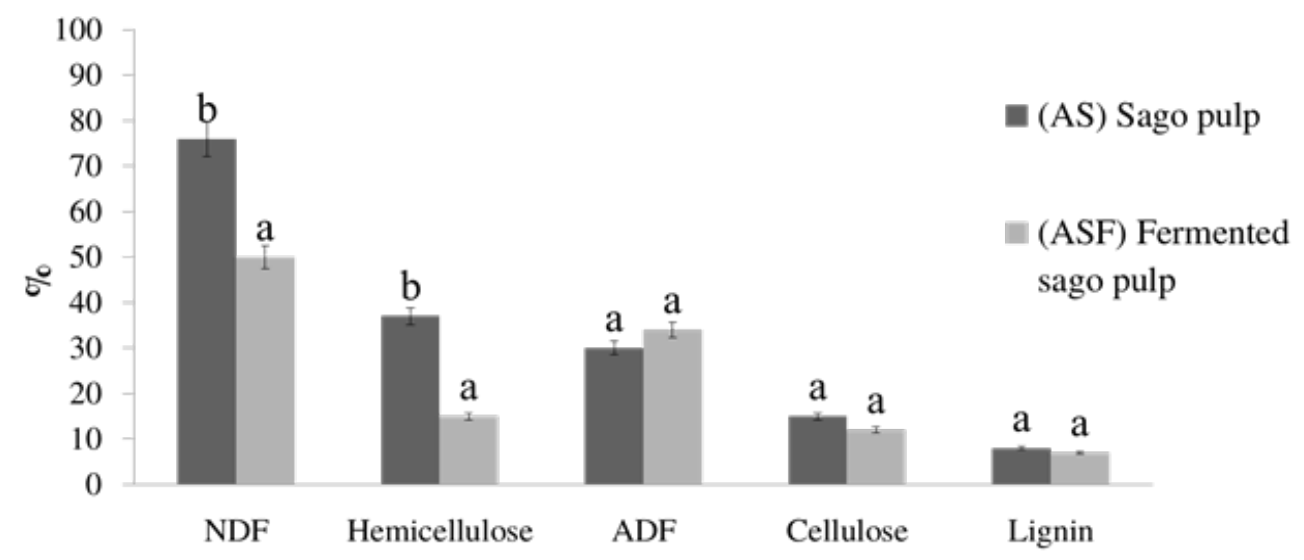

Figure 1. The fiber fraction contents of unfermented sago pulp (AS) and sago pulp fermented using $50 \mathrm{~g} / \mathrm{kg}$ tapai yeast for 72 hours (ASF). Different letters above the bars indicate a significant difference $(\mathrm{P}<0.05)$.

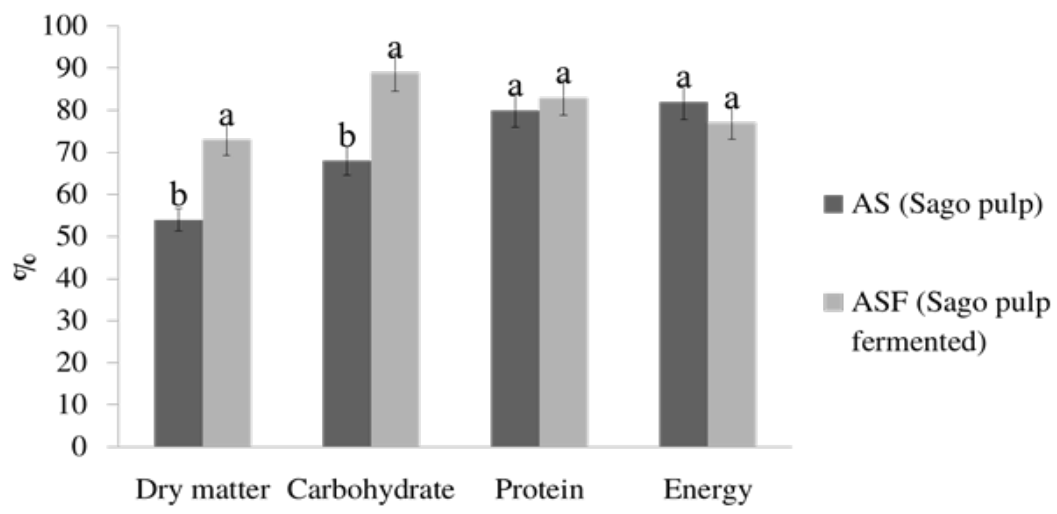

Figure 2. The digestibility of the material, carbohydrate, protein, and energy of sago pulp fermented with $50 \mathrm{~g} / \mathrm{kg}$ tapai yeast for 72 hours. 
The fermentation treatment could increase the dry material digestibility of sago pulp by $34 \%$ and the carbohydrate digestibility by $21 \%$, but there were no significant changes in the protein digestibility or energy digestibility.

The result of the blood glucose content (Figure 3 ) demonstrated that at the 0 hours after the 24hour fast the blood glucose of the Nile tilapia was below $40 \mathrm{mg} / \mathrm{dL}$ and started to increase in the $1^{\text {st }}$ hour and reach a peak in the $2^{\text {nd }}$ hour post treatment feed administration. The fermented sago pulp (ASF) treatment demonstrated the highest blood glucose at $134 \pm 6.00 \mathrm{mg} / \mathrm{dL}$ during the $2^{\text {nd }}$ hour. On the other hand, the highest blood glucose in the reference feed treatment and sago pulp (AS) treatment occurred in the $2^{\text {nd }}$ hour and only reached a range of $120 \pm 14.00 \mathrm{mg} / \mathrm{dL}$ and $94 \pm 5.00 \mathrm{mg} / \mathrm{dL}$, respectively. The blood glucose in the fish in all the treatments began to decrease from the $3^{\text {rd }}$ to the $5^{\text {th }}$ hour.

\section{Growth assessment}

The growth assessment that compared the feed with different carbohydrate source treatments (cassava flour, sago pulp, and fermented sago pulp) at $18 \%$ demonstrated different results between treatments (Table 5). The treatment using fermented sago pulp (ASF) demonstrated SGR, liver glycogen, fat retention, and protein retention values that were higher $(\mathrm{P}<0.05)$ than the treatment with sago pulp (AS), and were not significantly different from that with cassava flour $(G)$ except for protein retention, which was higher in ASF compared to that of G treatment. Feed conversion ratio in ASF treatment was lower than that of AS treatment, but was comparable

Table 5. The initial biomass, final biomass, specific growth rate, feed conversion rate, protein retention, fat retention, hepatosomatic index, and liver glycogen of the Nile tilapia at the end of the study

\begin{tabular}{lccc}
\hline \multirow{2}{*}{ Assessment parameter } & \multicolumn{2}{c}{ Treatment $(18 \%$ of carbohydrate source $)$} \\
\cline { 2 - 4 } & $\mathrm{G}$ & $\mathrm{AS}$ & ASF \\
\hline Initial weight $(\mathrm{g})$ & $3.72 \pm 0.09^{\mathrm{a}}$ & $3.77 \pm 0.74^{\mathrm{a}}$ & $3.68 \pm 0.57^{\mathrm{a}}$ \\
Final weight (g) & $23.42 \pm 2.90^{\mathrm{a}}$ & $22.53 \pm 2.36^{\mathrm{a}}$ & $26.10 \pm 1.98^{\mathrm{a}}$ \\
SGR (\%/day) & $3.10 \pm 0.13^{\mathrm{ab}}$ & $2.98 \pm 0.18^{\mathrm{b}}$ & $3.31 \pm 0.12^{\mathrm{a}}$ \\
FCR & $1.09 \pm 0.05^{\mathrm{a}}$ & $1.30 \pm 0.05^{\mathrm{b}}$ & $1.18 \pm 0.10^{\mathrm{ab}}$ \\
Survival (\%) & $80.00 \pm 21.08^{\mathrm{a}}$ & $80.00 \pm 12.17^{\mathrm{a}}$ & $90.00 \pm 3.84^{\mathrm{a}}$ \\
Protein retention (\%) & $35.26 \pm 5.97^{\mathrm{b}}$ & $31.58 \pm 4.77^{\mathrm{b}}$ & $47.34 \pm 5.23^{\mathrm{a}}$ \\
Fat retention (\%) & $65.54 \pm 22.48^{\mathrm{ab}}$ & $47.80 \pm 12.02^{\mathrm{b}}$ & $85.58 \pm 5.44^{\mathrm{a}}$ \\
HSI & $2.12 \pm 0.17^{\mathrm{a}}$ & $1.72 \pm 0.31^{\mathrm{a}}$ & $2.06 \pm 0.32^{\mathrm{a}}$ \\
Liver glycogen & $0.12 \pm 0.03^{\mathrm{a}}$ & $0.06 \pm 0.02^{\mathrm{b}}$ & $0.10 \pm 0.03^{\mathrm{ab}}$ \\
\hline
\end{tabular}

Notes: Different superscript letters after the average values ( \pm standard deviation) in the same row indicate a significant difference $(\mathrm{P}<0.05)$. $\mathrm{SGR}=$ specific growth rate, $\mathrm{FCR}=$ feed conversion ratio, HSI= hepatosomatic index.

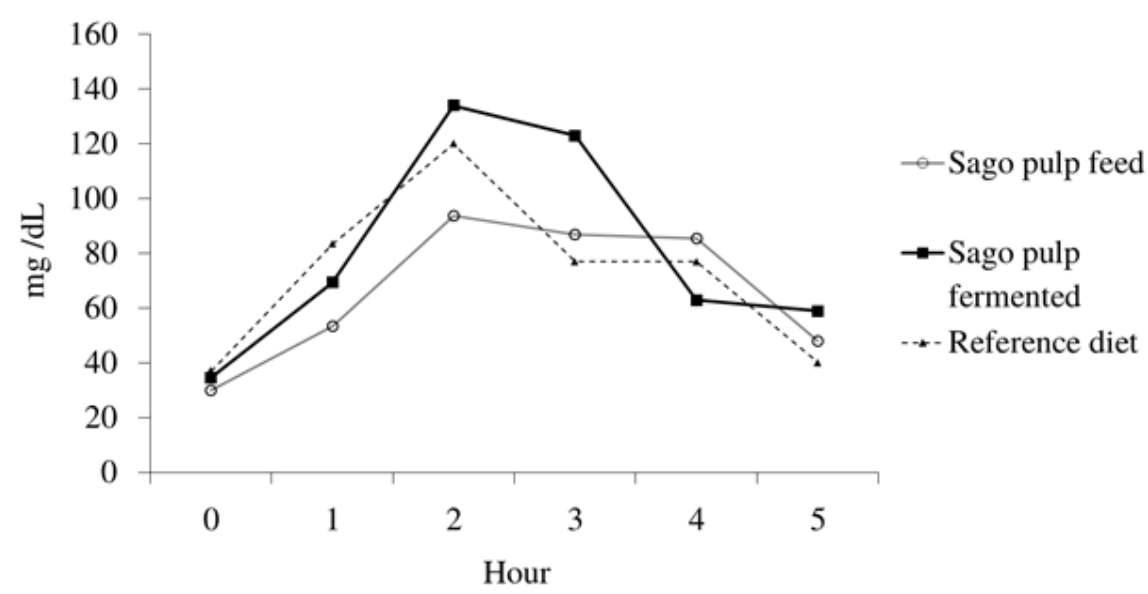

Figure 3. Changes in the blood glucose concentration of Nile tilapia after being given Sago pulp feed and sago pulp fermented with $50 \mathrm{~g} / \mathrm{kg}$ tapai yeast for 72 hour. 
to that of $G$ treatment. The final weight, survival and HSI were not significantly different between treatments.

\section{Discussion}

The first stage of the study revealed that the type of fermentor had an effect on the decrease in sago pulp's crude fiber. The present study clearly demonstrated that the types of fermentors that could decrease crude fiber were tapai yeast and Baker's yeast. Yeast (both tapai and Baker's yeast) has been suggested to be able to perform well on sago pulp substrate. The sago pulp substrate provided the nutrients required for optimum growth of yeast and the fermentation process succeeded. The successful fermentation was proven by the change in the sago pulp substrate nutrient composition in particular the decrease in crude fiber by $35.76 \%$. The results of the present study support a previous study by Sumardiono et al. (2018) where pre-treatment of sago pulp with $4 \% \mathrm{NaOH}$ and fermentation with $1 \%$ Trichoderma sp for 14 days could decrease the crude fiber of sago pulp from $33.37 \%$ to $17.36 \%$ and increase the protein from $4.00 \%$ to $7.96 \%$. In contrast with previous studies, treatment with rumen fluid did not have any effect on the crude fiber content of sago pulp flour. This is likely due to the incompatibility between the sago pulp substrate and the microorganisms and enzymes in the sheep rumen, causing the microorganisms and enzymes to demonstrate less than optimum performance. It is also possible that the presence of an inhibiting compound in the sago pulp that hindered the performance of the enzymes and microorganisms in the sheep rumen.

Tapai yeast contain a number of microorganisms from yeast and bacteria group such as Bacillus spp, Rhizopus sp, Candida parapsilosis, C. melinii, C. lactosa, C. solani, Hansenula subpelliculosa, Rhizopus oligosporus, Aspergillus flavus, A. oryzae, and Hansenula malanga (Barus, 2013; Aslamyah, 2018). Yeast produces a number of extracellular enzymes such as amylase, amyloglucosidase, pectinase, cellulase, catalase, and glucosidase (Hardjo et al., 1989) which degrade the sago pulp substrate so that it could be utilized by the microorganisms to grow and develop. A few Bacillus spp produce enzymes that can hydrolyze oligosaccharide into easily digestible sugar (Ghani et al., 2007). Specifically, Rhizopus sp in tapai yeast produces the amylolytic glucoamylase enzyme which can decrease amylose and amylopectin content by hydrolyzing the $\alpha-1.4$ and $\alpha-1.6$ glycoside link in the carbohydrate compound (Linggang et al., 2012). In addition, the microorganisms in the yeast can produce cellulase which degrades cellulose and hemicellulose into glucose (Ginting, 2018).

The different fermentor dose and incubation period treatments in the treatment with tapai yeast and Baker's yeast could decrease the crude fiber with a varied degree of decrease, but the greatest decrease was demonstrated by the tapai yeast treatment at a dose of $50 \mathrm{~g} / \mathrm{kg}$ which was $35.76 \%$. This suggested that the ratio between the amount of the fermentor and the amount of substrate and incubation period had an effect on the success of the fermentation process. The incubation length had an effect on the crude fiber content of the sago pulp. During the first 24 hours of the incubation, no changes were seen in the sago pulp's crude fiber content. This was probably because during this time period the microorganisms found in the yeast experienced a lag phase or adaptation period to a new environment. The decrease in crude fiber started to become apparent between the $48^{\text {th }}$ to $72^{\text {nd }}$ hour which was suggested to be the exponential phase where the fermentor microorganisms had actively degraded the fiber to a simpler material or compound. Meanwhile, during the $96^{\text {th }}$ hour, the microorganisms began to enter the stationary phase where the growth of the microorganisms began to be limited by the availability of one or more nutrients or substrate. This was signified by the lack of any change in the crude fiber content in the sago pulp during the $96^{\text {th }}$ hour. The results of the present study support a previous study (Santos, 2016) which demonstrated that Aspergillus niger and Rhizopus produced endoglucanase optimally after 70.35 hours at $29.56^{\circ} \mathrm{C}$ and cellulase after 72.48 hours at $27.86^{\circ} \mathrm{C}$. Aslamsyah (2018) demonstrated that the use of a combination between $1.5 \%$ tapai yeast as a source of Rhizophus sp and 1.5\% Baker's yeast as a source of Saccharomyces $\mathrm{sp}$ for the fermentation of the green strain Kappaphycus alvarezii seaweed flour for 72 hours could decrease the crude fiber by $28.60 \%$, from $15.73 \%$ to $11.23 \%$. Meanwhile, Kurniati (2017) reported that the optimum incubation of Jatropha seeds using a $0.3 \%$ fermentor dose (Aspergillus niger $0.15 \%$ and $0.15 \%$ Rhizopus oryzae) was 72 hours with the greatest decrease in crude fiber up to $21.36 \%$. As for the fermentation of sago pulp, Ginting (2018) demonstrated that the fermentation of sago pulp using $1 \%$ "Ginta" local microorganism (MOL) up to 144 hours resulted 
in an increased protein content in the sago pulp from $3.22 \%$ to $5.58 \%$ and a decrease in fiber content from $19.52 \%$ to $18.23 \%$. The results of this particular study were still lower than the results of the present study which demonstrated the fermentation of sago pulp using tapai yeast at a dose of $50 \mathrm{~g} / \mathrm{kg}$ and a shorter incubation, 72 hours, could decrease the crude fiber from $18.76 \%$ to $12.05 \%$ and increase the protein content from $1.72 \%$ to $6.23 \%$. Another study by Sumardiono et al. (2018) demonstrated that immersion of sago pulp in a $\mathrm{NaOH}$ solution and fermentation using Trichoderma sp for 14 days could decrease the crude fiber content from $33 \%$ to $17 \%$ and increase the protein content from $4 \%$ to $8 \%$. The comparison between the results above indicated that the success of the fermentation is influenced by the type of fermentor, the fermentor dose, and the incubation length.

The treatment by fermentation using tapai yeast at a dose of $50 \mathrm{~g} / \mathrm{kg}$ and an incubation period of 72 hours appeared to have an effect on the fiber fraction content. Fermentation with this method resulted in a decrease in NDF by $32.68 \%$ and hemicellulose by $60.39 \%$. However, the $\mathrm{ADF}$, cellulose and lignin fiber fractions showed relatively no changes. A previous study by Yanti et al. (2014) revealed that fermentation of rice bran using S. cerevisiae and A. niger could decrease the NDF by $4.85 \%$ and hemicellulose by $40.98 \%$ and surprisingly increased the cellulose and lignin content. On the other hand, the study by Santoso et al. (2017) revealed that the fermentation of agricultural waste substrate using a combination of microbes (lactic acid bacteria, yeast, and cellulolytic bacteria) could decrease the ADF and NDF fiber fractions. The ADF fiber fraction is a fraction of fiber which includes cellulose and lignin from plant cell walls and some xylan and other components (Kramer et al., 2012). Moreover, Messana et al. (2013) stated that the enzymes produced by microbes could decrease the NDF level in substrates from various plants.

In the digestibility test, the fermentation treatment could improve both dry matter digestibility and carbohydrate digestibility of sago pulp. The improved ASF digestibility might relate to the decrease in the sago pulp's crude fiber after the fermentation treatment. The results of the present study demonstrated that crude fiber could be broken down into simpler materials so the NDF and hemicellulose fiber fraction decreased and sago pulp became more easily digested (Santoso et al., 2017). The fermentation treatment could also change the chemical structure of the components of a certain material into simpler forms.

The improved digestibility of ASF would have a positive effect on nutrient absorption. This was seen in the result of the blood glucose measurements which revealed that the glucose absorption in the $2^{\text {nd }}$ hour post feed administration in the fish treated with ASF was higher than that of fish treated with AS. The study by Aslamsyah (2018) demonstrated that the maximum absorption of glucose from the fermentation of the Gracilaria gigas seaweed occurred three hours post feeding. This result suggested that the use of fermented sago pulp could improve glucose absorption. Glucose is an energy source for animals that will be converted into a form of chemical energy (ATP) (Kamalam et al., 2017). If the energy obtained from carbohydrate sources is adequate, the utilization of energy from other sources such as fat and protein would decrease, leading to retention of protein and fat in the body. This was proven by the significantly higher fat and protein retention value than that of the AS treatment.

The surplus of glucose originating from carbohydrate absorption which is not used as an energy source will be stored as glycogen or lipid in the liver ( $\mathrm{Li}$ et al. 2016). In the present study, the liver glycogen content in the ASF treatment was not significantly different from that of the AS treatment. It was suggested that this could be because the amount of glucose contributed by the ASF feed could be utilized optimally as an energy source. In addition, the plasma glucose regulation in omnivorous fish such as Nile tilapia is known to be fairly efficient, which is evident in the fact that carbohydrate intake from feed could trigger glycolysis and lipogenesis and reduce gluconeogenesis, the synthesis of glucose from non-carbohydrate compounds (Qiang, 2013).

The availability of an energy source from carbohydrates could play a role in the proteinsparing effect, the utilization of energy from non-protein sources so protein could be utilized optimally for growth (Kamalam et al., 2017). Nile tilapia is an omnivorous fish that effectively utilizes carbohydrate, leading to more efficient utilization of feed protein sources in building the body (Boonanuntanasarn, 2018). The growth and protein-sparing factors are strongly related to the main function of carbohydrate as an oxidative substrate in muscle tissue and blood cells. The availability of carbohydrates in fish feed could 
decrease gluconeogenesis, leading to a decrease in amino acid oxidation as an energy source and more optimum use of these amino acids in protein synthesis (Kamalam et al., 2017). The improved efficiency in protein utilization was demonstrated by the increased protein retention followed by an increased SGR and a decreased FCR in the treatment with ASF compared to those in the treatment with AS. Velasques et al. (2015) stated that utilization of up to $25 \%$ fermented duckweed in Nile tilapia had no adverse effect on the SGR or FCR, whereas the study conducted by Farizaldi (2017) demonstrated that the use of $20 \%$ fermented coconut pulp resulted in the highest growth rate, feed retention, and FCR in catfish. Virnanto et al. (2016) reported that the use of $20 \%$ fermented azolla flour (Azolla microphylla) resulted in the best growth and feed efficiency in giant gourami.

\section{CONCLUSION}

Fermentation using tapai yeast at a dose of 50 $\mathrm{g} / \mathrm{kg}$ for 72 hours could decrease the crude fiber content and improve dry matter and carbohydrate digestibility of sago pulp so that it could be used as a source of carbohydrate in Nile tilapia feed.

\section{REFERENCES}

Adeni DSA, Abd-Aziz S, Bujang K, Hassan MA. 2010. Bioconversion of sago residue into value added products. African Journal of Biotechnoly 14: 2016-2021.

Adeni DSA, Bujang K, Hasan MA, Azis. 2013. Recovery of glucose from residual starch of sago hampas for bioethanol production. BioMed Research International 1: 1-8.

Alfons JB, Rivaie AA. 2011. Sagu mendukung ketahanan pangan dalam menghadapi dampak perubahan iklim. Perspektif 2: 81-91.

Amos. 2011. Dampak limbah pengolahan sagu skala kecil terhadap mutu air anak sungai di Kelurahan Cibuluh Bogor. JIHP 5: 32-39.

AslamsyahS, Muhammad YK, Badraeni, Akbar MT. 2018. Effect of fermented seaweed addition on blood glucose level, hepatosomatic index, and gastric evacuation rate of milkfish, Chanos chanos larvae. AACL Bioflux 11: 226-231.

Barus T, Amanda K, Adi Y. 2013. Diversity of Amylase-producing Bacillus spp. from "Tape" (fermented cassava). HAYATI Journal of Biosciences 20: 1-10.
Boonanuntanasarn S, Araya J, Suksan K, Elisabeth J, Vinsent V, Cristine B, Lucia M, Stephane P. 2018. Adaptation of nile tilapia Oreochromis niloticus to different levels of dietary carbohydrates: New insights from a long term nutritional study. Aquaculture. 1: $58-65$.

Santos TCD, George A, Aila RDB, Aureliano JVP, Renata CFB, Marcelo F. 2016. Production and characterization of cellulolytic enzymes by Aspergillus niger and Rhizopus sp. by solid state fermentation of prickly pear. Rev Caatinga 29: 222-233.

Dubowski KM. 2008. An o-toluidine method for body-fluid glucose determination. Clinical Chemistry 11: 1919-1920.

Farizaldi, Novirman J, Jafrinur, Yeti M. 2017. The effect of fermented coconut waste to the growth of catfish Clarias sp.. International Journal of Agricultural Sciences 1: 21-27.

Ghani M, Ansari A, Aman A, Zohra RR, Siddiqui NN, Qader SAU. 2013. Isolation and characterization of different strains of Bacillus licheniformis for the production of commercially significant enzymes. Pak J Pharm Sci 26: 691-697.

Ginting N, Pase E. 2018. Effect of incubation time of sago Metroxylon sago waste by local microorganism"ginta" on $\mathrm{pH}$, crude protein, and crude fiber content. IOP Conf. Series: Environtal Earth Sciences 130: 012-022.

Hardjo SS, Indrasti NS, Takjuddin B. 1989. Biokonversi: Pemanfaatan Limbah Industri Pertanian (The Usage of Agriculture Waste Industry). Bogor, Indonesia: Pusat Antar Universitas Pangan dan Gizi IPB.

Henriksson PJG, Chadag VM., Michael JP. 2017. Evaluation of different aquaculture feed ingredients in Indonesia using life cycle assessment. IJoLCAS 1: 13-21.

Huisman EA. 1987. The Principles of Fish Culture Production. Netherland (EU): Departmen of Aquculture, Wegeningen University.

Kamalam BS, Medale F, Panserat S. 2017. Utilisation of dietary carbohydrates in farmed fishes: New insights on influencing factors, biological limitations and future strategies. Aquaculture 467: 3-27.

Kramer M, Weisbjerg MR, Lund P, Jensen CS, Pedersen MG. 2012. Estimation of indigestible NDF in forages and concentrates from cell wall composition. Animal feed science and technology 177: 40-51.

Kurniati T, Nurlaila L, Lim. 2017. Effect of 
inoculum dosage Aspergillus niger and Rhizopus oryzae mixture with fermentation time of oil seed cake Jatropha curcas L. to the content of protein and crude fiber. IOP Conf Series: Journal Physics: Conf Series 824: 012-064.

Lai JC, Rahma N, Toh W. 2013. Characterization of sago pith waste and its composites. Industrial Crops and Products. 45: 319-326.

Li X, Xiaoming Z, Dong H, Yunxia Y, Junyan J, Shouqi X. 2016. Carbohydrate utilization by herbivorous and omnivorous freshwater fish species: a comparative study on gibel carp Carassius auratus gibelio. Var CAS III and grass carp Ctenopharyngodon idellus. Aquaculture Research 47: 128-139.

Messana JD, Berchielli T., Arcuri PB, Reis RA, Canesin RC, Ribeiro AF, Fiorentini G, Fernandes JJDR. 2013. Rumen fermentation and rumen microbes in Nellore steers receiving diets with different lipid contents. Revista Brasileira de Zootecnia. 42: 204-212.

Muhsafaat L, Sukria HA, Suryahadi. 2015. Kualitas protein dan komposisi asam amino ampas sagu hasil fermentasi Aspergillus niger dengan penambahan urea dan zeolit. Jurnal Ilmu Pertanian Indonesia 20: 124-130.

Opiyo MA, Cecilia MG, Jonathan MM, Harrison CK. 2014. Growth performance carcass composition and profitability of nile tilapia Oreochromis niloticus fed commercial and on-farm made fish feed in earthen ponds. International Journal Fisheries and Sciences. 5: 12-17.

Qiang J, Yang H, He J, Wang H, Zhu ZX, Xu P. 2013. Comparative study of the effects of two high-carbohydrate diets on growth and hepatic carbohydrate metabolic enzyme responses in juvenile gift tilapia Oreochromis niloticus. Turkish Journal of Fisheries and Aquatic Sciences 14: 515-525.

Rosli MI, Abdul MAN, Mohd ST, Lee PC. 2018. Simulation of a fluidized bed dryer for the drying of sago waste. Energies 11: 23-83.

Sadh PK, Surekha D, Joginder SD. 2018. Agroindustrial wastes and their utilization using solid state fermentation: a review bioresour. Bioprocess 5: 1 .

Santoso B, Widayati TW, Hariadi BT. 2017. Nutritive value in vitro fermentation characteristics and nutrient digestibility of agro-industrial by products-based complete feed block enriched with mixed microbes. Pakistan Journal of Nutrition 16: 470-476.
Sanlier N, Busra BG, Aybuke CS. 2017. Health benefits of fermented foods. Critical Reviews in Food Science and Nutrition 25: 1-21.

Sumardiono S, Aditya DWN, Farel RA, Isti P. 2018. Livestock feed production from sago solid waste by pretreatment and anaerobic fermentation process. MATEC Web of Conferences 156: 03044.

Takeuchi T. 1988. Fish nutrition and mariculture: Laboratory work chemical evaluation of dietary nutrition. In: watanabe T. Tokyo, Japan: Kanagawa International Fisheries Training Center. pp 179-229.

Tiro BMW, Beding PA, Baliadi Y. 2018. The utilization of sago waste as cattle feed. IOP Conference Series: Earth and Environmental Science 119: 012-028.

Van Soest PJ, Robertson JB, Lewis BA. 1991. Methods for dietary fiber, neutral detergent fiber and non-starch polysaccharides in relation to animal nutrition. Journal Dairy Science 74: 583-3597.

Velasques YC, Kijora C, Wuertz S, Schulz C. 2015. Effect of fermented aquatic macrophytes supplementation on growth performance, feed efficiency and digestibility of Nile tilapia Oreochromis niloticus juvenil fed low fishmeal diet. Livestock Research for Rural Development 27: 71-77.

Virnanto LA, Diana R, Istiyanto S. 2016. Pemanfaatan tepung hasil fermentasi azolla Azolla microphylla sebagai campuran pakan buatan untuk meningkatkan pertumbuhan dan kelulushidupan ikan gurame Osphronemus gouramy. Journal of Aquaculture Management and Technology 5: 1-7.

Watanabe T. 1998. Fish Nutrition and Mariculture. Tokyo, Japan: Tokyo University of Fisheries.

Wedemeyer GA, Yasutake WT. 1977. Clinical methods for the assesment of the effects of environmental stress on fish health. In: technical paper of the us fish and wildlife service. Washington DC, USA : Departement of the Interior Fish and Wildlife Service,.

Yanti Y, Kawamoto Y, Miyagi T, Rahmi B, Surahmanto, Purnomoadi A. 2014. The effect of types of microorganism and temperature on fiber content of fermented rice straw. Sains Peternakan 12: 114-119.

Yusuf MA, Romli M, Suprihatin, Wiloso EI. 2018. An environmental impact analysis of semi - mechanical extraction process of sago starch: life cycle assessment (LCA) perspective. IOP Conference Series: Earth and Environmental Science 147: 012-036. 